University of Nebraska - Lincoln

DigitalCommons@University of Nebraska - Lincoln

Faculty Papers and Publications in Animal

Science

Animal Science Department

2003

\title{
Supplementation to Meet Metabolizable Protein Requirements of Primiparous Beef Heifers: II. Pregnancy and Economics
}

\author{
H. H. Patterson \\ University of Nebraska-Lincoln \\ Don C. Adams \\ University of Nebraska-Lincoln, dadams1@unl.edu \\ Terry J. Klopfenstein \\ University of Nebraska-Lincoln, tklopfenstein1@unl.edu \\ R. T. Clark \\ University of Nebraska-Lincoln \\ B. Teichert \\ University of Nebraska-Lincoln
}

Follow this and additional works at: https://digitalcommons.unl.edu/animalscifacpub

Part of the Animal Sciences Commons

\footnotetext{
Patterson, H. H.; Adams, Don C.; Klopfenstein, Terry J.; Clark, R. T.; and Teichert, B., "Supplementation to Meet Metabolizable Protein Requirements of Primiparous Beef Heifers: II. Pregnancy and Economics" (2003). Faculty Papers and Publications in Animal Science. 534.

https://digitalcommons.unl.edu/animalscifacpub/534

This Article is brought to you for free and open access by the Animal Science Department at DigitalCommons@University of Nebraska - Lincoln. It has been accepted for inclusion in Faculty Papers and Publications in Animal Science by an authorized administrator of DigitalCommons@University of Nebraska - Lincoln.
} 


\title{
Supplementation to meet metabolizable protein requirements of primiparous beef heifers: II. Pregnancy and economics ${ }^{1}$
}

\author{
H. H. Patterson' ${ }^{2}$ D. C. Adams ${ }^{3}$, T. J. Klopfenstein, R. T. Clark, and B. Teichert \\ Department of Animal Science, University of Nebraska, Lincoln 68583-0908
}

\begin{abstract}
Metabolizable protein (MP) requirements of spring calving heifers increase over the winter due to advancing gestation. The MP content of grazed winter forage is low, which may result in an MP deficiency. The objective was to compare the response of supplementing pregnant yearling heifers to meet MP requirements versus conventional $\mathrm{CP}$ supplementation. In 1997-98 and in 1998-99, pregnant, March-calving heifers $(2,120$ animals; $358 \mathrm{~kg})$ at two locations of a commercial ranch in the Nebraska Sandhills, were used following breeding through calving as 2-yr-olds (cows). Heifers were randomly allotted to one of two supplementation treatments (about 265 heifers/treatment) each year at each of two locations (Ashby and Whitman, NE). Treatments were 1) supplementation to meet MP requirements (MPR) or 2) supplementation to meet $\mathrm{CP}$ requirements (CPR). Heifers grazed upland range and meadow and were offered supplements three times weekly from mid-September to mid- or late-February. Increasing amounts of meadow hay were fed from mid-December through calving. After supplementation ended in February, heifers were managed in one group at each location until the following October. Body
\end{abstract}

weights and body condition scores were taken in September, February, and October. Two-yr-old pregnancy rates were determined via rectal palpation in October. Capital budgeting techniques were used to determine the economic return of supplementation strategies. There were no differences in BW $(P=0.41)$ or body condition score $(P=0.99)$ change during the winter among treatment groups across years and locations, but MPR cows were heavier $(425 \mathrm{~kg})$ than CPR cows $(421 \mathrm{~kg})$ at the time of 2-yr-old pregnancy testing $(P=$ $0.07)$. Pregnancy rate was higher $(P=0.001)$ in the MPR (91\%) compared to the CPR treatment (86\%). Regression analysis showed that the response of the MPR treatment on pregancy rates tended to be negatively correlated with precalving body condition score $(P=$ $0.11)$, body condition score loss over the winter $(P=$ 0.07 ), and body condition score at weaning of the first calf $(P=0.08)$. The improvement in 2 -yr-old pregnancy by supplementing to meet MP requirements improved the value of each bred heifer by $\$ 13.64$. We conclude that balancing MP requirements during gestation may result in a subsequent increase in 2-yr-old pregnancy and increase the value of young females.

Key Words: Cows, Heifers, Pregnancy, Profitability, Protein

(C2003 American Society of Animal Science. All rights reserved.

J. Anim. Sci. 2003. 81:563-570

\section{Introduction}

In order for young cows to recover costs of development and 2-yr-old wintering, they often must stay in the production system for multiple years. Failed reproduction can have marked effects on the value of young females (Meek et al., 1999). Nutritional systems that facilitate

\footnotetext{
${ }^{1}$ Published with the approval of the director of the Univ. of Nebraska-Lincoln, Institute of Agr. and Natur. Resources, Agr. Res. Div. as Journal Ser. No. 13349.

${ }^{2}$ Current location: Department of Animal and Range Science, South Dakota State Univ., Rapid City, SD.

${ }^{3}$ Correspondence: Univ. of Neb. West. Central Research and Extension Center; Rt. 4, Box 46 A; North Platte, NE 69101.

Received December 12, 2001.

Accepted May 27, 2002.
}

increased 2-yr-old pregnancy have the potential to increase expected lifetime profitability of the pregnant heifer. Due to the time value of money, however, it is important to estimate the expected returns on any additional investment into young females. Capital budgeting techniques can be used to estimate the profitability of inputs into young females (Meek et al., 1999).

Microbial crude protein production is often inadequate in meeting the metabolizable protein (MP) requirement of young, growing cows, resulting in a need for supplemental undegradable intake protein (UIP, Klopfenstein, 1996). Patterson et al. (2000a) reported that winter supplementing pregnant heifers to meet MP requirements improved heifer weight gain in the fall, but MP supplementation had little effect on weight and body condition score change from October to February. Improving the nutrient status of cows and heifers before calving can decrease postpartum interval (Bellows and Short, 1978), 
which may improve reproductive performance (Short et al., 1990).

Reproductive responses to supplementing heifers grazing Nebraska Sandhills winter range to meet MP requirements vs CP requirements have not been documented. It is hypothesized that supplementing to meet MP requirements will improve 2-yr-old pregnancy and thus the net present value of pregnant heifers. The objective of this study was to determine the response of supplementing primiparous heifers grazing fall-winter range to meet MP vs CP requirements on $\mathrm{BW}$ and body condition score change, 2-yr-old pregnancy, and the net present value of pregnant heifers.

\section{Materials and Methods}

In 1997-98 (1,059 heifers; $350 \mathrm{~kg})$ and 1998-99 (1,061 heifers; $369 \mathrm{~kg}$ ), pregnant heifers at a commercial ranch in the Nebraska Sandhills were used following breeding as yearlings through pregnancy testing as 2 -yr-olds. Heifers were crossbred between Red Angus (60\%), Hereford, Tarentaise, Simmental, and other breeds. Bulls used on yearling and 2-yr-olds were of similar breeding. The average calving date was March 25 of each year. Heifers were randomly allotted to one of two treatments (approximately 265 heifers/treatment) each year at both the Ashby and Whitman, NE, locations of the Rex Ranch. Heifers grazed fall-winter upland range and meadow from mid-September to mid- or late- February of each year. Range sites at each location included sands, choppy sands, and subirrigated meadows. Treatments were 1) supplementation to meet MP requirements (MPR) or 2) supplementation to meet CP requirements (CPR). Feather meal was used as a source of UIP in the MPR supplement (Table 1). Supplements were pelleted $(5 \mathrm{~cm})$ and fed on the ground to each treatment group three times weekly. In 1997-98, supplements were fed from September 17 to February 27. In 1998-99, supplements were fed from September 18 to February 15. The MPR supplement was fed to meet MP requirements, supplying increased CP and UIP over time (Table 2). The amount of CPR supplement fed increased from September to October, then remained constant throughout the supplementation period (fed to meet CP requirements; Table 2 ). Commercial mineral and salt were available as selffed supplements at all times.

At each location, heifers were rotated through pastures that had been previously grazed in the summer. Heifers at Ashby rotated through five pastures each year, whereas Whitman heifers rotated through six pastures. Each treatment group was given access to pastures with similar standing herbage and level of grazing pressure. All heifers within a treatment group grazed and were supplemented together. Meadow hay was fed at the discretion of the manager at each location in each year, depending on weather and forage availability. Each treatment group at each location was fed similar amounts of hay during each year. Hay was fed three times weekly on alternate days from supplement feeding.
Table 1. Composition of supplements (DM basis) fed to heifers grazing Nebraska Sandhills range from September to February of 1997-98 and 1998-99

\begin{tabular}{lcc}
\hline \hline Ingredient & $\mathrm{MPR}^{\mathrm{b}}$ & $\mathrm{CPR}^{\mathrm{c}}$ \\
\hline Ingredients & - & \\
Cottonseed meal & 40.2 & 58.8 \\
Feather meal & - & - \\
Soybean meal & 30.2 & 17.8 \\
Sunflower meal & 26.2 & 13.7 \\
Wheat middlings & - & - \\
Distillers grains & 2.1 & 3.4 \\
Molasses (cane) & - & 2.1 \\
Urea & 1.1 & 2.8 \\
Salt & 0.2 & 1.1 \\
Vitamin A premix & - & 0.2 \\
Limestone & & 0.1 \\
Nutrients & 91.4 & 89.6 \\
DM, \% AF & 93.8 & 91.7 \\
OM & 52.9 & 50.9 \\
CP & 28.0 & 14.0 \\
UIP & 0.8 & 0.3 \\
Calcium & 0.8 & 1.0 \\
Phosphorus & & \\
\hline
\end{tabular}

${ }^{\text {aS }}$ Supplements fed three times weekly.

${ }^{\mathrm{b}}$ Formulated to meet metabolizable protein requirement.

${ }^{\mathrm{c}}$ Formulated to meet $\mathrm{CP}$ requirement.

${ }^{\mathrm{d}}$ Undegradable intake protein.

Hay, which was in the form of large round bales, was fed on the ground. In 1997-98, heifers at Ashby were fed hay at a rate of approximately $1.8 \mathrm{~kg} /$ heifer daily (OM basis) from December 15 to January 1, 3.6 kg/d in January, and $7.2 \mathrm{~kg} / \mathrm{d}$ in February. In 1997-98, Whitman heifers were fed hay at a rate of $4 \mathrm{~kg} / \mathrm{d}$ in December, 5.5 $\mathrm{kg} / \mathrm{d}$ in January, and $7.3 \mathrm{~kg} / \mathrm{d}$ in February. In 1998-99, Ashby heifers were fed hay at a rate of $1.8 \mathrm{~kg} / \mathrm{d}$ from Jan 1 to Jan $18,3.6 \mathrm{~kg} / \mathrm{d}$ in late January, and $5.4 \mathrm{~kg} / \mathrm{d}$ in February. In 1998-99, Whitman heifers were fed hay at a rate of approximately $1.8 \mathrm{~kg} / \mathrm{d}$ in early December, 5.4 $\mathrm{kg} / \mathrm{d}$ from December 15 to January 1 and $7.3 \mathrm{~kg} / \mathrm{d}$ in January and February. Laboratory analyses of the hay fed during each winter are shown in Table 3. Samples were not available from Whitman in 1997-98, but CP analysis from a commercial laboratory was supplied by the ranch. For nutrient modeling purposes, 1997-98 Whitman hay energy values were estimated from hay analyzed in 1998-99 with similar CP content.

Heifers from each treatment at each location were managed in one group from the time of supplement termination to the following October of each year. Approximately $7.3 \mathrm{~kg} / \mathrm{d}$ (OM basis) of meadow hay (Table 3 ) was fed to each heifer daily, and range was available from the time of supplement termination until calving. After calving, approximately $8.8 \mathrm{~kg}(\mathrm{OM})$ of meadow hay (average $10.2 \% \mathrm{CP}, 2.2 \%$ UIP, $78 \% \mathrm{NDF}$ ) and $1.8 \mathrm{~kg}$ of alfalfa hay (20\% CP, $2.5 \%$ UIP, $68 \% \mathrm{NDF}$ ) were fed daily to each cow until available grazing in early May. Lactating 2 -yr-old cows were exposed to a mix of mature and yearling bulls for $60 \mathrm{~d}$ beginning June 10 of each year.

In 1997-98, heifers were individually weighed (no prior feed restriction) and assigned a body condition score 
Table 2. Amount of supplemental DM, OM, CP and undegradable intake protein (UIP) fed to heifers grazing sandhills winter range in 1997-98 and 1998-99 supplemented to meet metabolizable protein (MPR) or crude protein requirements (CPR) $)^{\mathrm{a}, \mathrm{b}}$

\begin{tabular}{|c|c|c|c|c|c|c|c|c|}
\hline \multirow[b]{2}{*}{ Date } & \multicolumn{4}{|c|}{ MPR } & \multicolumn{4}{|c|}{ CPR } \\
\hline & $\mathrm{DM}$ & $\mathrm{OM}$ & $\mathrm{CP}$ & UIP & $\mathrm{DM}$ & $\mathrm{OM}$ & $\mathrm{CP}$ & UIP \\
\hline Sept. 17 to 30 & 249 & 234 & 132 & 70 & 81 & 75 & 41 & 11 \\
\hline Oct. 1 to 31 & 311 & 292 & 165 & 87 & 407 & 373 & 207 & 57 \\
\hline Nov 1 to 30 & 457 & 428 & 242 & 128 & 407 & 373 & 207 & 57 \\
\hline Dec 1 to 31 & 457 & 428 & 242 & 128 & 407 & 373 & 207 & 57 \\
\hline Jan 1 to 31 & 457 & 428 & 242 & 128 & 407 & 373 & 207 & 57 \\
\hline Feb 1 to 15 & 498 & 467 & 263 & 139 & 407 & 373 & 207 & 57 \\
\hline Feb 16 to $27^{\mathrm{c}}$ & 747 & 701 & 395 & 209 & 407 & 373 & 207 & 57 \\
\hline
\end{tabular}

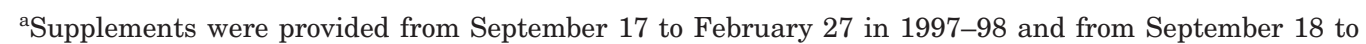
February 15 in 1998-99. Various amounts of meadow hay were provided from mid-December through February.

bSupplements fed three times weekly as 5-cm pellets on the ground.

${ }^{\mathrm{c} N o t}$ applicable to $1998-99$.

on September 15 and 16, February 27 and 28, and on October 21 and 22 (one day for each location). Body condition scores were assigned by two trained technicians based on palpation of the ribs and vertebra. Scores were assigned on a 1 (emaciated) to 9 (obese) scale (Richards et al., 1986). Weaning weights were taken on calves (no prior feed restriction) on August 14 at Whitman and September 3 at Ashby. Pregnancy was determined via rectal palpation on October 21 and 22. In 1998-99, heifers were weighed and body condition scored on September 16 and 17, February 16 and 18, and October 25 and 27. Weaning weights were taken on calves on August 19 at Whitman and September 2 at Ashby. Pregnancy was determined via rectal palpation on October 25 and 27.

Diets of grazed forage were collected using esophageally fistulated cows on October 6, December 5, and February 10 in 1997-98, and diets were collected October 20, January 15, and February 18 in 1998-99. Fistulas in cows were previously established in accordance to University Animal Care and Use Guidelines. At each location on each date, diets were collected using three cows in the pasture where each treatment group would be subsequently rotated. The February 18 diets in 1998-99 were collected following grazing by the heifers. Diets were

Table 3. Laboratory analysis of hay fed to heifers grazing winter range at two locations in the Nebraska Sandhills in the winters of 1997-98 and 1998-99 (OM basis) ${ }^{\mathrm{a}}$

\begin{tabular}{lccccr}
\hline \hline & \multicolumn{2}{c}{$1997-98$} & & \multicolumn{2}{c}{$1998-99$} \\
\cline { 2 - 3 } Item & Whitman & Ashby & & Whitman & Ashby \\
\hline CP, \% & 7.6 & 9.4 & & 9.4 & 8.1 \\
UIP, \% & NA & 2.4 & & 2.8 & 2.4 \\
NDF, \% & NA & 80.6 & & 81.7 & 82.1 \\
IVOMD, \% & NA & 51.5 & & 44.0 & 45.0 \\
\hline
\end{tabular}

${ }^{a} \mathrm{NA}$ : samples not available for analysis.

${ }^{b}$ Undegradable intake protein.

${ }^{\mathrm{c}}$ In vitro organic matter disappearance. collected by allowing cows to graze without the esophageal plug for 20 to $30 \mathrm{~min}$. Extrusa was collected in screen-bottom bags and subsequently frozen. Extrusa samples were freeze-dried, and one-half of each sample was ground to pass a 1-mm screen and one-half a 2-mm screen using a Wiley Mill. Samples were analyzed for DM and OM by AOAC (1990) methods (1-mm grind). In vitro organic matter disappearance (IVOMD) and IVDMD were determined using a modified Tilley and Terry (1963; 48-h incubation in ruminal fluid followed by $24 \mathrm{~h}$ in acid and pepsin) procedure with the addition of $1 \mathrm{~g}$ urea to the buffer mixture (Weiss, 1994). Forage UIP (and thus degradable intake protein; DIP) was determined as described by Klopfenstein et al. (2001). In brief, samples ground to $2 \mathrm{~mm}$ were incubated in situ for $48 \mathrm{~h}$ and NDF extraction was performed on the in situ bags (Mass et al., 1999). Forage UIP was determined by the amount of neutral detergent insoluble nitrogen remaining after $48 \mathrm{~h}$. A 48-h incubation period was chosen to represent the estimated mean retention time of forage particles in the rumen (2\% rate of passage as determined by Lamb, 1996). The mean nutrient content (or analytical value) of the six samples collected in the two pastures at each location was used to represent the diet quality for each treatment at that time. Samples of meadow hay were taken with a core sampling device and analyzed as described above.

Intake and nutrient data were used in the NRC (1996) model to determine nutrient balance of the heifers at the time of each diet collection. Intakes were estimated using data reported by Patterson et al. (2000a). In general, forage OM intake (range + hay) was estimated to be 2.0\% of BW in October, 1.9\% in December, 1.8\% in January, and $1.7 \%$ in February. Patterson et al. (2000a) showed that the MPR and CPR treatments did not affect forage intake; therefore, we assumed supplement and nutrient balance had no impact on forage intake. Range diet CP and UIP were calculated on an OM basis and adjusted to DM (for modeling) assuming $10.0 \%$ ash. Diet TDN was estimated from IVDMD. Microbial efficiency was 
assumed to be $11.5 \%$ in October, when estimated diet TDN values ranged from 59 to $63 \%$. In the January 1999 samples from Ashby, diet TDN was estimated to be $56 \%$. In this case, $10.0 \%$ microbial efficiency was assumed. All other diets were between 46 and $53 \%$ estimated TDN, and a microbial efficiency of $9.5 \%$ was assumed. Estimates of microbial efficiency were based on a maxium efficiency of $13 \%$ with decreasing microbial efficiency with decreasing forage quality (NRC, 1996).

Budgets were set up starting with an arbitrary 100 pregnant heifers both in 1998 and 1999, corresponding to the years that supplement treatments were applied. Budgets were consistent with management where the experiment was conducted and were similar to that reported by Meek et al. (1999) working with the same operation. Actual data from the operation were used to determine pregnancy, weaning, cull, and death rates, annual cow costs, and the weight of cattle marketed (either calves or cull females). Costs and performance data were available on four management groups of cattle: 1 ) 2-yr-olds, 3-yr-olds, mature cows (4 to 7 yr) and old cows (10 to $15 \mathrm{yr}$ ). All costs were inflated by $2.0 \%$ per year. Because costs and performance were similar across locations, one set of costs and performance data was used to represent cattle from both locations.

A traditional marketing system was assumed with calves and open cows sold in October and cull cows in May. Both bull and heifer calves were assumed to be sold at weaning, although the ranch described in this study selects replacements from the heifer calf pool. The value of replacement heifers was assumed to equal the value of market heifers. Revenue was calculated using actual prices received for 1998 through 2000. Market prices for years 2001 through age 15 of the cows were estimated by historical data reported from 1990 back through 1978 (Wellman, 1998). For example, 1990 prices were used to represent 2001, 1989 to represent 2002, and so on. The 1978-90 prices were used to estimate timing in the cattle cycle consistent with observed timing at the time of the experiment. Annual net cash flow was determined for the original set of 100 females for each year up to when the cattle turned $15 \mathrm{yr}$ of age. The inventory of cows changed each year within each budget, as it was reduced by the number of cows sold or dead. All cows remaining at age 15 were considered to be sold.

Since the CPR treatment was the conventional supplementation protocol for this operation, the 2-yr-old pregnancy rate for the CPR treatment was used as the "base" for each location within each year. Pregnancy rate of 2yr-old cows from the MPR treatment was then used in the budget to determine change in lifetime cash flow due to the change in 2-yr-old pregnancy associated with that treatment. Effects of treatments on 2-yr-old pregnancy were assumed to not affect future production parameters.

Net present value of the bred heifers (2-yr-old production year) was determined from the budgets using the formula: net present value $=\mathrm{E} 1 /(1+\mathrm{i})^{1}+\mathrm{E} 2 /(1+\mathrm{i})^{2}+\ldots$ $+\mathrm{En} /(1+\mathrm{i})^{\mathrm{n}}$, where $\mathrm{E}$ is net cash flow in each year 1 through $\mathrm{n}(\mathrm{n}=15$ in this case), and $\mathrm{i}$ is the discount rate.
A discount rate of $8.0 \%$ was used for all calculations, and this was assumed to be a real rate of discount. The net present value of pregnant heifers was calculated for both treatments at each location within each year. Net present value per head was calculated by dividing total net present value by 100 .

The MPR supplement cost an average of $\$ 19.93 /$ heifer in 1997-98 and $\$ 14.97 /$ heifer in 1998-99. The CPR supplement averaged $\$ 16.91 /$ heifer in $1997-98$ and $\$ 14.38 /$ heifer in 1998-99. The difference between MPR and CPR supplement cost was lower in 1998-99, because of ingredient costs and the fact that the trial ended earlier in February of 1999 before the scheduled increase in the amount of MPR to be fed.

Cow BW, body condition score, ADG, body condition score change, calf weaning weight, and calf weight per day of age at weaning were analyzed using Proc GLM of SAS (Sas Inst. Inc., Cary, NC). Treatment, ranch, and year were class variables and all two-way interactions were included in the model $(n=8)$. Treatment $\times$ year $\times$ ranch was the error term. Two-year-old pregnancy data were analyzed as binomial data with chi-square analysis using the LOGIT function of Proc GENMOD of SAS (which allows categorical data to be modeled like regression). Treatment $\times$ year $\times$ ranch was the error term $(\mathrm{n}=$ 8 ; events $=1,871$; trials $=2,119$ ). Treatment, ranch, and year were class variables, and all two-way interactions were used in the model. Linear and quadratic regressions of the pregnancy response (MPR-CPR) on production traits at each ranch during each year were tested in Proc GLM.

\section{Results and Discussion}

Although cow BW did not differ between treatments in September and February, cows on the MPR treatment had a higher BW $(P=0.07)$ in October (2-yr-old pregnancy check time) than CPR cows (Table 4). Treatments did not differ for any other trait. Cows in Whitman during 1997-98 had lower BW and body condition score in October than Whitman cows in 1998-99, resulting in year $\times$ ranch interactions $(P=0.03)$ for those traits. In addition, there was a treatment $\times$ ranch interaction $(P=0.08)$ for October body condition score; MPR cows had a higher October body condition score than CPR cows in Ashby but not Whitman. There was a treatment $\times$ year interaction $(P=0.03)$ for the change in body condition score from September to October. The interaction was present because MPR cows had more body condition score loss during that time than CPR cows in 1997-98, but not 1998-99. Ashby cows had a larger overall (September to October) body condition score loss in 1998-99 than 199798 , resulting in a year $\times$ ranch interaction $(P=0.01)$. Calves from Ashby had higher weaning weights in 199798 than in 1998-99, resulting in a year $\times$ ranch interaction $(P=0.07)$ for that trait.

Cows on the MPR treatment had a higher $(P=0.001)$ 2-year-old pregnancy rate (91\%) than cows on the CPR treatment $(86 \%)$. A year $\times$ ranch interaction $(P=0.0004)$ 
Table 4. Body weight, body condition score (BCS), and calf weaning weight of heifers supplemented to meet metabolizable protein requirements (MPR) or CP requirements (CPR) across two locations and two years (1997-98 and 1998-99) in the Nebraska Sandhills ${ }^{\text {a }}$

\begin{tabular}{lccc}
\hline \hline Item & MPR & CPR & SEM $^{b}$ \\
\hline Sept. BW, kg & 359.6 & 357.5 & 0.6 \\
Feb. BW, kg & 415.4 & 410.4 & 2.0 \\
Oct. BW, kg & 425.4 & 421.3 & 0.3 \\
ADG, Sept. to Feb., kg & 0.35 & 0.33 & 0.01 \\
ADG, Feb. to Oct., kg & 0.04 & 0.04 & 0.01 \\
ADG, Sept. to Oct., kg & 0.16 & 0.16 & $<0.01$ \\
BCS, Sept. & 5.77 & 5.76 & $<0.01$ \\
BCS, Feb. & 5.21 & 5.21 & 0.05 \\
BCS, Oct. & 5.34 & 5.33 & 0.01 \\
Calf weaning weight, kg & 156.4 & 154.8 & 0.7 \\
Calf WDA, kg & 1.02 & 1.02 & 0.01 \\
\hline
\end{tabular}

a 2,120 total heifers were group fed supplement in treatment groups across two locations and two years.

${ }^{\mathrm{b}} \mathrm{n}=8$.

'Treatments differ: $P=0.07$.

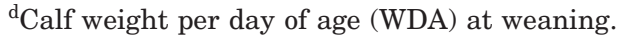

existed for pregnancy rate. In 1997-98, pregnancy rates averaged $95 \%$ and $80 \%$ at Ashby and Whitman, respectively. In 1998-99, pregnancy rates were $92 \%$ and $87 \%$ at Ashby and Whitman, respectively. Regression analysis of the pregnancy response of the MPR treatment (MPR$\mathrm{CPR}$ at each ranch during each year) revealed that the pregnancy response tended to be linearly (negatively) related to body condition score in February $(P=0.11)$, body condition score in October at pregnancy checking $(P=0.08)$, and body condition score loss over the winter $(P=0.07)$.

The effects of prepartum nutrition on reproduction have been documented. Bellows and Short (1978) reported that cows and heifers with moderate levels of prepartum nutrition had lower weights and body condition scores at calving, longer postpartum intervals, and a lower percentage of cows cycling at the start of the breeding season than cows and heifers on high levels of prepartum nutrition. In young cows, extended postpartum intervals can have negative effects on pregnancy (Short et al., 1990). In the present study, the trend for pregnancy response to be related to February body condition score may be due to the importance of body condition score at calving on postpartum interval. Richards et al. (1986) reported that the postpartum interval was $12 \mathrm{~d}$ longer if cows calved at a body condition score of 4 or lower than if they calved at a body condition score of 5 or greater. When body condition score at calving was lower in the current study, pregnancy rates were reduced and the response to the MPR treatment was larger. The change in body condition score during the winter also may have affected pregnancy and the response to the MPR treatment. Lalman et al. (1997) concluded that body condition score at calving was a better indicator of postpartum interval than pre- or postpartum BW or body condition score change. In contrast, Dunn and Moss
(1992) suggested that cows in moderate condition (body condition score of 4 to 6 ) at calving that gained weight precalving had shorter postpartum intervals than cows in similar condition that lost weight precalving.

The effects of the MPR treatment on pregnancy cannot be explained by improved body condition score or weight change prior to calving. Although MPR heifers were heavier in October, calf weaning weight data do not lend support to altered milk production. The difference between treatments in October BW likely carried over from the numerical differnces noticed in February (prior to calving). Patterson et al. (2000a) found a small response of MP supplementation on winter weight change of heifers in one of two years. Karges (1990), using BW change as an indicator, concluded that cows consuming low-quality hay did not require gestational UIP supplementation. However, Miner et al. (1990) found that the addition of either blood meal or corn gluten meal to soybean meal supplements for gestating beef cows grazing on native range in Montana decreased body condition score loss over the winter compared to soybean meal alone or no supplementation. Effects of UIP supplementation during gestation may involve altered endocrinology in the postpartum cow. Lalman et al. (2000), working with beef heifers, found that the length of the postpartum interval was negatively correlated with serum levels of IGF-1 and insulin but positively correlated with serum GH. Protein supplementation has been shown to increase insulin release (Wiley et al., 1991). Insulin can interact with GH and its binding in the liver, which may affect IGF-1 release (Keisler and Lucy, 1996). Hormones such as IGF1 may affect tissue responsiveness to LH (Beam and Butler, 1999). Other compounds, such as amino acids, glucose, cholecystokinin, and neuropeptide $\mathrm{Y}$, also have been implicated as potential links of nutrition to reproduction (Keisler and Lucy, 1996).

The increase in pregnancy rate reported for the MPR treatment is similar to that reported with gestational fat supplementation. Bellows (1997) reported that pregnancy rates in a 53-d breeding season were higher in heifers fed $4.9 \%$ fat diets during gestation (83.3\%) than heifers fed $1.7 \%$ fat diets during gestation (79.6\%). Lammoglia et al. (1996) found that high levels of fat (14 d prepartum to $22 \mathrm{~d}$ postpartum) decreased circulating estradiol concentrations before calving compared to low or moderate levels. The authors hypothesized that the enzyme $17 \alpha$-hydroxylase, which converts progesterone to estradiol, was suppressed in the high-fat supplemented cows. In addition, the authors reported greater plasma concentrations of progesterone and cholesterol in cows supplemented with fat. Although the exact mechanisms of prepartum nutrition on subsequent reproduction are not fully understood, supplementation of UIP during gestation, like fat supplementation, may increase pregnancy rates.

The CP, UIP, and IVOMD of diets collected during the $2 \mathrm{yr}$ are shown in Tables 5 (Ashby) and 6 (Whitman). Crude protein of cow diets was higher in October of 1997 than October 1998. Diets were collected earlier in 1997 
Table 5. Means and standard deviations of nutrient composition (OM basis) of diets collected by esophageally fistulated cows grazing winter range near Ashby, NE, in 1997-98 and 1998-99a

\begin{tabular}{lccccccc}
\hline \hline & \multicolumn{3}{c}{$1997-98$} & & \multicolumn{3}{c}{$1998-99$} \\
\cline { 2 - 3 } \cline { 7 - 8 } Nutrient & October & December & February & & October & January & February \\
\hline $\mathrm{CP}, \%$ & $18.3 \pm 1.6$ & $7.5 \pm 1.2$ & $6.7 \pm 0.7$ & & $8.5 \pm 1.7$ & $7.4 \pm 0.6$ & $7.7 \pm 0.7$ \\
UIP, \% & $1.3 \pm 0.2$ & $2.0 \pm 0.1$ & $2.2 \pm 0.3$ & & $1.7 \pm 0.1$ & $2.0 \pm 0.2$ & $2.0 \pm 0.3$ \\
DIP, \% CP & 92.9 & 73.3 & 67.2 & & 80.0 & 73.0 & 74.0 \\
IVOMD, \% & $61.9 \pm 2.5$ & $51.8 \pm 2.8$ & $53.2 \pm 2.1$ & & $60.4 \pm 1.7$ & $58.9 \pm 2.0$ & $55.9 \pm 1.2$ \\
\hline
\end{tabular}

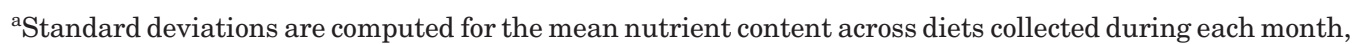
not across laboratory duplications; $\mathrm{n}=6$.

${ }^{b}$ Undegradable intake protein. Samples composited within pasture for each date for UIP determination; $\mathrm{n}=2$.

${ }^{\mathrm{c}}$ Degradable intake protein, calculated from UIP.

${ }^{\mathrm{d}}$ In vitro organic matter disappearance.

(October 6) than in 1998 (October 22), and advancing season may partially explain the difference. Cows at Ashby selected diets from a riparian area in October 1997, explaining the $18.3 \%$ CP measured in those diets. Diet quality does not explain the difference in pregnancy rates or over-winter body condition score loss between the Ashby and Whitman locations. Diet CP and IVOMD were generally higher in all situations in this study than reported at another location in the Nebraska Sandhills during the same period of time (Patterson et al., 2000a). Diets in the present study were collected prior to grazing by the heifers. Diet quality has been shown to decline in the Nebraska Sandhills with increased grazing pressure (Yates et al., 1982; Downs, 1997; Patterson et al., 2000b). However, the diets collected after removal of heifers from pastures in February of 1999 were not lower in CP or IVOMD than reported at earlier times. The diets reported here are similar in quality to those reported from $3 \mathrm{yr}$ of collection in the Sandhills by Lardy (1997). Most of the change in CP was from DIP, as UIP remained fairly constant between 1.5 and $2.2 \%$ of $\mathrm{OM}$. The largest effects on nutrient balance may have been created by different intakes or hay qualities (Table 3).

The nutrient balances of the heifers are shown in Tables 7 (Ashby) and 8 (Whitman). At Ashby, nutrient bal- ances were similar between 1997-98 and 1998-99 until February. At Ashby, both MP and energy were more deficient in February 1999 than in 1998, potentially explaining a greater response to the MPR treatment in 1999 (pregnancy rates were $95 \%$ for both treatments in 1998; pregnancy rates were $95 \%$ and $88 \%$ for MPR and CPR, respectively, in 1999). The amount of hay fed at Ashby in 1998-99 was less than the previous year, and the hay was poorer quality. At Ashby, an MP deficiency did not occur in the CPR treatment until February. The MPR treatment supplied enough UIP to meet the MP requirements in February. Degradable intake protein was deficient in the MPR treatment at both locations in October 1998 due to high diet digestibility and moderate CP. The MP balances reported account for DIP deficiency, so MP balance was still positive in October 1998 at Ashby. At Whitman, MP became limiting to the CPR treatment in February of both years, and the MPR supplement alleviated the deficiency. Energy was markedly deficient in February of both years at Whitman, potentially explaining the lower pregnancy rates at Whitman (pregnancy rates were $84 \%$ and $75 \%$ in 1998 and 89 and $85 \%$ in 1999 for MPR and CPR, respectively). These data show that the pregnancy response to the MPR supplement likely came from an improved MP balance in late gesta-

Table 6. Means and standard deviations of nutrient composition (OM basis) of diets collected by esophageally fistulated cows grazing winter range near

Whitman, NE, in 1997-98 and 1998-99a

\begin{tabular}{|c|c|c|c|c|c|c|}
\hline \multirow[b]{2}{*}{ Nutrient } & \multicolumn{3}{|c|}{$1997-98$} & \multicolumn{3}{|c|}{ 1998-99 } \\
\hline & October & December & February & October & January & February \\
\hline $\mathrm{CP}, \%$ & $14.0 \pm 5.5$ & $10.3 \pm 1.8$ & $6.5 \pm 0.6$ & $8.1 \pm 1.0$ & $8.3 \pm 1.1$ & $7.5 \pm 1.3$ \\
\hline UIP, \% & $1.5 \pm 0.1$ & $1.8 \pm 0.2$ & $2.0 \pm 0.1$ & $1.8 \pm 0.1$ & $2.1 \pm 0.3$ & $2.2 \pm 0.1$ \\
\hline $\mathrm{DIP}, \% \mathrm{CP}^{\mathrm{c}}$ & 89.3 & 82.5 & 69.2 & 77.8 & 74.7 & 70.7 \\
\hline IVOMD, $\% \mathrm{~d}$ & $58.7 \pm 1.6$ & $53.8 \pm 3.0$ & $56.4 \pm 2.8$ & $63.4 \pm 3.9$ & $54.3 \pm 2.0$ & $58.2 \pm 2.6$ \\
\hline
\end{tabular}

aStandard deviations are computed for the mean nutrient content across diets collected during each month, not across laboratory duplications; $\mathrm{n}=6$.

${ }^{\mathrm{b}}$ Undegradable intake protein. Samples composited within pasture for each date for UIP determination; $\mathrm{n}=2$.

cDegradable intake protein, calculated from UIP.

${ }^{\mathrm{d}}$ In vitro organic matter disappearance. 
Table 7. Estimated intake and nutrient balance of pregnant heifers grazing winter range near Ashby, NE, when supplemented to meet metabolizable protein requirements (MPR) or CP requirements (CPR)

\begin{tabular}{|c|c|c|c|c|c|c|}
\hline \multirow[b]{2}{*}{ Item } & \multicolumn{2}{|c|}{ October } & \multicolumn{2}{|c|}{ December/January } & \multicolumn{2}{|c|}{ February } \\
\hline & MPR & CPR & MPR & CPR & MPR & CPR \\
\hline \multicolumn{7}{|l|}{$1997-98$} \\
\hline Range intake, kg OM & 7.2 & 7.2 & 7.1 & 7.1 & 0.2 & 0.2 \\
\hline Hay intake, kg OM & 0.0 & 0.0 & 0 & 0 & 6.6 & 6.6 \\
\hline Supplement intake, kg OM & 0.27 & 0.36 & 0.41 & 0.36 & 0.45 & 0.36 \\
\hline NEm balance, $\mathrm{Mcal} / \mathrm{d}$ & 3.7 & 3.9 & 0.7 & 0.6 & -1.9 & -2.1 \\
\hline DIP balance, $\mathrm{g} / \mathrm{d}^{\mathrm{a}}$ & 722 & 787 & 92 & 132 & 190 & 223 \\
\hline MP balance, $\mathrm{g} / \mathrm{d}^{\mathrm{b}}$ & 24 & -1 & 88 & 33 & 27 & -43 \\
\hline \multicolumn{7}{|l|}{ 1998-99 } \\
\hline Range intake, kg OM & 7.2 & 7.2 & 5.3 & 5.3 & 1.6 & 1.6 \\
\hline Hay intake, kg OM & 0.0 & 0.0 & 1.7 & 1.7 & 5.2 & 5.2 \\
\hline Supplement intake, kg OM & 0.27 & 0.36 & 0.41 & 0.36 & 0.68 & 0.36 \\
\hline NEm balance, Mcal/d & 3.9 & 4.0 & 0.4 & 0.4 & -2.8 & -3.4 \\
\hline DIP balance, $\mathrm{g} / \mathrm{d}^{\mathrm{a}}$ & -17 & 49 & 37 & 77 & 170 & 162 \\
\hline MP balance, $\mathrm{g} / \mathrm{d}^{\mathrm{b}}$ & 32 & 18 & 78 & 24 & 53 & -78 \\
\hline
\end{tabular}

${ }^{\mathrm{a}} \mathrm{DIP}=$ degradable intake protein.

${ }^{\mathrm{b}} \mathrm{MP}=$ metabolizable protein.

tion. The improved MP balance during late gestation was more beneficial to pregnancy rates when heifers were lower in body condition and (or) energy balance during that time.

Effects of gestational UIP supplementation occurred even though supplements were not fed immediately before or after calving. Although heifers started calving in early March, the last days to feed the treatment supplements were 25 and $35 \mathrm{~d}$ before the average calving date in 1998 and 1999, respectively. The $1996 \mathrm{NRC}$ equations predicted the meadow hay and range diet offered during this time was deficient in MP (150 to $200 \mathrm{~g} / \mathrm{d}$ deficient). Metabolizable protein requirements increase exponentially during the 3 wk before calving (NRC, 1996). Al- though it is surprising that reproduction was positively affected without supplementation 25 to $35 \mathrm{~d}$ before calving, it is possible that greater improvements in 2-yr-old pregnancy rate would have been noticed had UIP been supplemented through the calving season. The NRC (1996) predicted that cows were approximately $125 \mathrm{~g} / \mathrm{d}$ deficient in MP at $30 \mathrm{~d}$ postpartum.

Net present value of heifers on the MPR treatment averaged $\$ 887.51$ compared to $\$ 872.17$ for heifers on the CPR treatment. When the additional cost of the MPR treatment was accounted for, the average return for implementation of the MPR treatment was $\$ 13.64$ per heifer. Assuming 2-yr-old pregnancy was the only production trait changed, supplementing heifers to meet MP

Table 8. Estimated intake and nutrient balance of pregnant heifers grazing winter range near Whitman, NE, when supplemented to meet metabolizable protein requirements (MPR) or $\mathrm{CP}$ requirements $(\mathrm{CPR})$

\begin{tabular}{|c|c|c|c|c|c|c|}
\hline \multirow[b]{2}{*}{ Item } & \multicolumn{2}{|c|}{ October } & \multicolumn{2}{|c|}{ December/January } & \multicolumn{2}{|c|}{ February } \\
\hline & MPR & CPR & MPR & CPR & MPR & CPR \\
\hline \multicolumn{7}{|l|}{$1997-98$} \\
\hline Range intake, kg OM & 7.2 & 7.2 & 2.6 & 2.6 & 0.2 & 0.2 \\
\hline Hay intake, kg OM & 0.0 & 0.0 & 4.5 & 4.5 & 6.6 & 6.6 \\
\hline Supplement intake, kg OM & 0.27 & 0.36 & 0.41 & 0.36 & 0.45 & 0.36 \\
\hline NEm balance, Mcal/d & 3.4 & 3.6 & -0.4 & -0.5 & -3.8 & -4.0 \\
\hline DIP balance, $\mathrm{g} / \mathrm{d}^{\mathrm{a}}$ & 415 & 479 & 245 & 286 & 211 & 244 \\
\hline MP balance, $\mathrm{g} / \mathrm{d}^{\mathrm{b}}$ & 41 & 16 & 123 & 65 & 19 & -51 \\
\hline \multicolumn{7}{|l|}{ 1998-99 } \\
\hline Range intake, kg OM & 7.2 & 7.2 & 0.4 & 0.4 & 0.2 & 0.2 \\
\hline Hay intake, kg OM & 0.0 & 0.0 & 6.6 & 6.6 & 6.6 & 6.6 \\
\hline Supplement intake, kg OM & 0.27 & 0.36 & 0.41 & 0.36 & 0.68 & 0.36 \\
\hline NEm balance, Mcal/d & 4.4 & 4.6 & -2.3 & -2.4 & -3.8 & -4.3 \\
\hline DIP balance, $\mathrm{g} / \mathrm{d}^{\mathrm{a}}$ & -70 & -5 & 210 & 251 & 254 & 246 \\
\hline MP balance, $\mathrm{g} / \mathrm{d}^{\mathrm{b}}$ & -10 & 7 & 78 & 20 & 62 & -69 \\
\hline
\end{tabular}

${ }^{\mathrm{a}} \mathrm{DIP}=$ degradable intake protein.

${ }^{\mathrm{b}} \mathrm{MP}=$ metabolizable protein. 
requirements increased the value of each bred heifer entering the system by $\$ 13.64$. These economic data show that improving pregnancy rate by strategic supplementation can add marked value to young beef females. The importance of reproduction in young breeding females to profitability has been demonstrated in previous studies (Meek et al., 1999)

Supplementing heifers over the winter to meet MP requirements improved 2-yr-old pregnancy rates. Improved 2-yr-old pregnancy resulted in the heifers having a greater value and expected profitability. The response of MP supplementation on reproduction was not caused by improved weight or body condition score change prior to calving, and the response may have involved endocrine mechanisms. Defining such mechanisms would help nutritionists to develop economical systems to optimize reproduction in young cows.

\section{Implications}

Improving reproduction in young females is important to ranch profitability, and nutritional management during gestation is important to reproduction. Large feed inputs into the pregnant heifer to improve reproduction may not be economically sustainable. Pregnant heifers may respond to supplemention to meet MP requirements, especially if they are losing body condition during the winter. Rather modest nutritional inputs into nutritionally stressed heifers can have marked effects on profitability.

\section{Literature Cited}

AOAC. 1990. Official Methods of Analysis. 14th ed. Assoc. Offic. Anal. Chem. Arlington, VA.

Bellows, R. A. 1997. Factors affecting calf survival. In: Proc. 15th Range Beef Cow Symp., Rapid City, SD. pp 141-150.

Bellows, R. A., and R. E. Short. 1978. Effects of precalving feed level on birth weight, calving difficulty and subsequent fertility. J. Anim. Sci. 46:1522-1528.

Beam, S. W., and W. R. Butler. 1999. Effects of energy balance on follicular development and first ovulation in postpartum dairy cows. J. Reprod. Fertil. (Suppl.). 54:411-424.

Downs, D. 1997. Diet composition of sandhills winter range and compensatory growth of yearling steers during summer grazing. M. S. thesis, Univ. of Nebraska, Lincoln.

Dunn, T. G., and G. E. Moss. 1992. Effects of nutrient deficiencies and excesses on reproductive efficiency of livestock. J. Anim. Sci. 70:1580-1593.

Karges, K. K. 1990. Effects of rumen degradable and escape protein on cattle response to supplemental protein on native range. $\mathrm{M}$. S. thesis, Univ. of Nebraska, Lincoln.

Keisler, D. H., and M. C. Lucy. 1996. Perception and interpretation of the effects of undernutrition on reproduction. J. Anim. Sci. 74(Suppl. 3):1-17.

Klopfenstein, T. 1996. Need for escape protein by grazing cattle. Anim. Feed Sci. Technol. 60:191-199.
Klopfenstein, T. J., R. A. Mass, K. W. Creighton, and H. H. Patterson. 2001. Estimating forage protein degradation in the rumen. J. Anim. Sci. 79 (E. Suppl.):E208-E217.

Lalman, D. L., D. H. Keisler, J. E. Williams, E. J. Scholljegerdes, and D. M. Mallett. 1997. Influence of postpartum weight and body condition change on duration of anestrus by undernourished suckled beef heifers. J. Anim. Sci. 75:2003-2008.

Lalman, D. L., J. E. Williams, B. W. Hess, M. G. Thomas, and D. H. Keisler. 2000. Effect of dietary energy on milk production and metabolic hormones in thin, primiparous beef heifers. J. Anim. Sci. 78:530-538.

Lamb, J. 1996. Plant maturity effects on intake, digestibility, and rumen kinetics of leaf and stem fractions of Sandhills grasses in beef steers. Ph.D. dissertation, Univ. of Nebraska, Lincoln.

Lammoglia, M. A., S. T. Willard, J. R. Oldham, and R. D. Randel. 1996. Effects of dietary fat and season on steroid hormonal profiles before parturition and on hormonal, cholesterol, triglycerides, follicular patterns, and postpartum reproduction in Brahman cows. J. Anim. Sci. 74:2253-2262.

Lardy, G. P. 1997. Protein supplementation of calves and cows grazing sandhills range and subirrigated meadow. Ph.D. dissertation, Univ. of Nebraska, Lincoln.

Mass, R. A., G. P. Lardy, R. J. Grant, and T. J. Klopfenstein. 1999. In situ neutral detergent insoluble nitrogen as a method for measuring forage protein degradability. J. Anim. Sci. 77:1565-1571.

Meek, M. S., J. C. Whittier, and N. L. Dalsted. 1999. Estimation of net present value of beef females of various ages and the economic sensitivity of net present value to changes in production. Prof. Anim. Sci. 15:46-52.

Miner, J. L., M. K. Petersen, K. M. Havstad, M. J. McInernery, and R. A. Bellows. 1990. The effects of ruminal escape protein or fat on nutritional status of pregnant winter-grazing beef cows. J. Anim. Sci. 68:1743-1750.

NRC. 1996. Nutrient requirements of beef cattle. 7th ed. National Academy Press, Washington, DC.

Patterson, H. H., D. C. Adams, and T. J. Klopfenstein. 2000a. Supplementation based on the metabolizable protein systems versus the crude protein system for primiparous heifers grazing winter range. J. Anim. Sci. 78(Suppl. 2):91. (Abstr.).

Patterson, H. H., T. J. Klopfenstein, D. C. Adams, W. H. Schacht, P. E. Reece, and A. E. Herron. 2000b. Summer grazing and fall grazing pressure effects on protein content and digestibility of fall range diets in the Nebraska Sandhills. Proc. West. Sec. Am. Soc. Anim. Sci. 51:316-319.

Richards, M. W., J. C. Spitzer, and M. B. Warner. 1986. Effect of varying levels of postpartum nutrition and body condition at calving on subsequent reproductive performance in beef cattle. J. Anim. Sci. 62:300-306.

Short, R. E., R. A. Bellows, R. B. Staigmiller, J. G. Berardinelli, and E. E. Custer. 1990. Physiological mechanisms controlling anestrus and infertility in postpartum beef cattle. J. Anim. Sci. 68:799-816.

Tilley, J. M. A., and R. A. Terry. 1963. A two-stage technique for the in vitro digestion of forages. J. Br. Grassl. Soc. 18:104-111.

Weiss, W. P. 1994. Estimation of digestibility of forages by laboratory methods. In: G. C. Fahey Jr., M. Collins, D. R. Mertens, and L. E. Moser (ed.) Forage Quality, Evaluation, and Utilization. pp 644-681. Am. Soc. of Agron., Crop Sci. Soc. of Am., Soil Sci. Soc. of Am., Madison, WI.

Wellman, A. 1998. Crop and Livestock Prices for Nebraska. Univ. of Nebraska Coop. Ext. Service. EC883, Lincoln.

Wiley, J. S., M. K. Petersen, R. P. Ansotegui, and R. A. Bellows. 1991. Production from first-calf beef heifers fed a maintenance or low level of prepartum nutrition and ruminally undegradable or degradable protein postpartum. J. Anim. Sci. 69:4279-4293.

Yates, D. A., D. C. Clanton, and J. T. Nichols. 1982. Effect of continuous grazing on the diet of steers. J. Range Manage. 35:339-341. 